порой и довольно абстрактный, характер, а также нередко указанные нормы содержат прямые отсылки к внутреннему праву государств [5].

Практическая реализация правовых норм международного характера обусловлена внутригосударственными и международными механизмами и способами взаимодействия. Так, международный механизм характеризуется как совокупность методов и норм международной правовой системы на основе которых реализуется совместная организационно-правовая деятельность субъектов международного права. Данный механизм направлен на реализацию целей и задач, которые заложены в международных обязательствах, договорах и нормативно-правовых актах. Международный механизм имеет отличие от внутригосударственного, так как второй обусловлен нормами национальной правовой системы, которые также взаимодействуют с нормами международного права. Процесс регламентации практической реализации процессуальных отношений на территории российского государства осуществляется на основе взаимодействия законодательных и подзаконных актов отечественной правовой системы при взаимодействии с нормами международного права.

Итогом имплементации является заимствование правовых институтов и норм международного права и последующее органичное, на сколько это возможно, изменение законодательства.

Таким образом, полагаем, что при принятии Российской Федерацией международноправовых норм, правило в ней содержащееся, не только включаются в правовую систему государства, но и делают ее соответствующим национальным элементом, который способен регулировать общественные отношения различной отраслевой принадлежности.

$$
* * *
$$

1. Карасёва Л.В. Значение норм международного частного права в регулировании трудовых отношений мигрантов из стран СНГ в Российской Федерации // автореферат диссертации на соискание ученой степени кандидата юридических наук / Российский государственный социальный институт. Москва, 2007.

2. Смоленский М.Б. Российское право в условиях современной глобализации: социокультурный аспект, перспективы развития, связь с международным правом // Наука и образование: хозяйство и экономика; предпринимательство; право и управление. 2021. № 2 (129). С. 67-71.

3. Пичугин Б.С. Соотношение международного и национального права Российской Федерации // Традиции и новации в системе современного российского права. Материалы ХХ Международной конференции молодых ученых. В 3-х томах. Москва, 2021. С. 206-208.

4. Конституция Российской Федерации (принята всенародным голосованием 12.12.1993) (с учетом поправок, внесенных Законами РФ о поправках к Конституции РФ от 30.12.2008 N 6-ФКЗ, от 30.12.2008 N 7-ФКЗ, от 05.02.2014 N 2-ФКЗ, от 01.07.2020 N 11-ФКЗ) // Собрание законодательства РФ, 01.07.2020, N 31, ст. 4398.

5. Nukusheva A., Ilyassova G., Kudryavtseva L., Popova L., Shayakhmetova Z., Jantassova A. TRANSNATIONAL CORPORATIONS IN PRIVATE INTERNATIONAL LAW: DO KAZAKHSTAN AND RUSSIA HAVE THE POTENTIAL TO TAKE THE LEAD? // Entrepreneurship and Sustainability Issues. 2020. T. 8. № 1. C. 496-512.

\title{
Удалов Д.Э. \\ К 25-летию закона «Об основах туристской деятельности в Российской Федерации»
} ФГОБУ ВО «Финансовый университет при Правительстве Российской Федераџии» (Россия, Москва)

doi: 10.18411/trnio-11-2021-267

\section{Аннотация}

В статье рассматриваются основные направления развития законодательства в сфере туристской деятельности. Анализируются правовые нормы, принимаемые в целях совершенствования процесса правового регулирования общественных отношений в области туристской индустрии.

Ключевые слова: туризм, туристская деятельность, закон о туризме, развитие законодательства, правовое регулирование. 


\section{Abstract}

The article discusses the main directions of development of legislation in the field of tourism activity. Legal norms adopted in order to improve the process of legal regulation of public relations in the field of tourism industry are analyzed. regulation.

Keywords: tourism, tourist activity, tourism law, development of legislation, legal

В ноябре 2021 г. исполняется 25 лет с момента принятия первого специального законодательного акта, регулирующего туристские отношения на территории нашей страны - федерального закона «Об основах туристской деятельности в Российской Федерации» [1] (далее - закон о туризме).

Туризм в настоящее время является одной из важнейших составляющих экономического, социального и культурного развития общества и современного государства. Актуальность темы выражается, в том, что несмотря на изменения, происходящие в стране как политического, социально-экономического, так и санитарно-эпидемиологического характера, правовое регулирование туристской деятельности осуществляется с соблюдением прав и свобод человека и гражданина, а также прав юридических лиц и законодательные органы своевременно реагируют на изменения, происходящие в обществе, и вносят соответствующие поправки в существующее законодательство в сфере туризма.

Необходимо отметить, что закон принимался в период формирования и становления современной российской правовой системы. В 90-е годы были приняты: Конституция Российской Федерации 1993 г.; Закон РФ от 25 июня 1993 г. № 5242-1 «О праве граждан Российской Федерации на свободу передвижения, выбор места пребывания и жительства в пределах Российской Федерации»; Гражданский кодекс Российской Федерации части первая и вторая 1994 и 1996 гг.; федеральные законы от 23 февраля 1995 г № 26-Ф3 «О природных лечебных ресурсах, лечебно-оздоровительных местностях и курортах», от 15 августа 1996 г. № 114-Ф3 «О порядке выезда из Российской Федерации и въезда в Российскую Федерацию» и др. нормативно-правовые акты, регулирующие общественные отношения, возникающие в процессе оказания различного рода услуг населению и порядка пересечения государственной границы.

К конституционным принципам, без которых невозможно было бы осуществить развитие туристской деятельности, относятся положения глав 1 и 2 Конституции Российской Федерации, в частности провозглашение России социальным государством (развитие детского, молодежного и социального туризма); право на отдых (возможность совершать путешествия); право на свободу передвижения (возможность беспрепятственного выезда и возвращения на территорию Российской Федерации - выездной и въездной туризм); право на благоприятную окружающую среду (осуществление курортной деятельности - лечебнооздоровительный туризм); право на доступ к культурной жизни (культурно-познавательный туризм); право на получение защиты интересов личности за пределами территории России консульская защита и покровительство.

В рамках данной работы туристская деятельность понимается как комплексная деятельность, включающая в себя также порядок организации участников, рассматриваемых отношений: туроператоров, турагентов, организаций, оказывающих экскурсионные услуги, гостиниц и иных средств размещения, предприятий общественного питания и других организаций, реализующих услуги туриста и экскурсантам в сфере транспорта, культуры, спорта, развлечений и т.д.

Рассмотрим теоретические положения, раскрывающие содержание законодательства и правового регулирования. Закон должен обладать такими признаками как легитимность и законность. А. Конт-Спонвиль, говорит о легитимности (legitimite), как о понятии, лежащем на границе между правом и моралью, с одной стороны, и правом, и политикой - с другой. Легитимно то, что в своем праве. Легитимность есть соответствие не просто закону (это законность), но и справедливости или высшему интересу [10, с. 270]. Юридический 
энциклопедический словарь определяет законность - как режим общественной жизни, который основан на системе требований по соблюдению законодательства всеми государственными органами, должностными лицами, предприятиями, учреждениями и гражданами. Законность есть, по сути, соблюдение всеми субъектами права законов и подзаконных актов. Законность предполагает реализацию двух условий: первое - наличие правовых, справедливых, научно обоснованных законов и второе - их выполнение, ибо только наличия даже самых совершенных законов будет недостаточно [17, с. 64].

Следует согласиться с мнением А.Н. Конева утверждающего, что наделение юридических документов юридической силой необходимо для того, чтобы, будучи примененным в практической юридической деятельности, породить определенные правовые последствия. Без легализации или при несоблюдении процедуры легализации юридический документ не будет порождать правовых последствий. Соответственно легализация юридических документов заключается в придании им юридической силы и подтверждении юридической силы юридического документа [16, с. 70-71].

Рассуждая о концепции развития законодательного регулирования деятельности в сфере туристской индустрии, необходимо определиться с понятием термина «концепция». В философской науке под концепцией понимается - взгляд на ту или иную проблему, включающий в себя ее четкую формулировку, понимание и объяснение. Соответственно под проблемой понимается - существенный вопрос, имеющий важное теоретическое и практическое значение, для решения которого либо недостаточно наличного знания, либо возможность его использования далеко не очевидна [11, с. 410, 512-513]. Таким образом можно констатировать, что проблемы возникающие в процессе применения положений законодательства в сфере туризма, вызывают необходимость внесения дополнений и изменений в действующие нормативно-правовые акты.

Принимая во внимание теоретические концепции правового регулирования туристской деятельности можно определенно сказать, что они вполне соотносятся с вопросами правового регулирования туристско-экскурсионной и гостинично-ресторанной деятельности, например:

- порядок охраны и защиты туристских ресурсов как природного, так и культурного характера;

- развитие различных видов туризма, например, социального (детского туризма, активного туризма);

- вопросы обеспечения безопасности туристской деятельности и др.

Правовой аспект регулирования туристской отрасли предполагает наличие основных понятий. В настоящее время в законе более 30 определений, характеризующих основные принципы деятельности участников туристских и связанных с ними отношений. Данные определения, можно классифицировать в зависимости от предмета регулирования, т.е. в зависимости от вида отношений в сфере туризма и смежных отраслей экономической деятельности, например.

a) Определения, содержащие само понятие туризма и характеризующие его виды (туризм, туризм внутренний / выездной / въездной / международный / самодеятельный / социальный / детский);

б) Определения, характеризующие основные виды деятельности в сфере туризма и правовой статус участников туристских и смежных с ними отношений (туристская деятельность, деятельность туроператора и турагента; деятельность экскурсовода (гида), гид-переводчика, инструкторапроводника; характеристику средств размещения, гостиниц; объектов туристской индустрии в целом, а также потребителей услуг - туриста, заказчика туристского продукта, экскурсанта);

в) Определения, характеризующие виды услуг, осуществляемых в процессе реализации договора о туристском обслуживании (туристский продукт и 
порядок его формирования, продвижения и реализации; характеристику ресурсов и отдельных видов услуг, в частности гостиничных услуг);

г) Определения, характеризующие правовой аспект, соблюдения прав потребителей туристских услуг на получение достоверной информации о качестве и безопасности получаемых ими услуг при реализации договорных отношений в сфере индустрии туризма (понятие классификации гостиниц / горнолыжных трасс / пляжей - необходимые для соблюдения норм качества и безопасности при их деятельности; электронная путевка, система навигации и ориентирования, туристский маршрут и функции информационных центров в сфере туризма - гарантирует получение достоверной информации, а также экстренная помощь - предусмотренная законом гарантия соблюдения прав туристов, в случае неисполнения договорных отношений) [12, с. $41 ; 15$, с. 9].

Правоотношения, которые возникают и реализуются в процессе деятельности субъектов предпринимательской деятельности, постоянно развиваются, соответственно должно меняться и законодательство. За время деятельности данного закона в него было внесено более 20 поправок, отражающих изменения правового регулирования туристских отношений. Рассмотрим некоторые из изменений в законодательстве о туризме, которые были вызваны решением проблем правового регулирования в данной сфере.

В 2016 г. были более детально прописаны нормы закрепляющие полномочия органов государственной власти Российской Федерации, органов государственной власти субъектов Российской Федерации и органов местного самоуправления в сфере туризма. Существенно дополнены права этих органов по созданию благоприятных условий для развития туризма. В финансовой составляющей деятельности, также произошли изменения, так для формирования резервного фонда стала предусматриваться пропорциональная система перечисления денежных средств в зависимости от количества туристов в сфере выездного туризма: 50 тыс. рублей - 10000 туристов; 100 тыс. рублей - 100000 туристов; 300 тыс. рублей - не менее 100000 , но не более 500000 туристов и 500 тыс. рублей - более 500000 туристов. Также в целях защиты прав туристов были внесены дополнения в регулирование договорных отношений, возникающих в процессе осуществления туроператорской деятельности [2]. Организационные отношения в сфере туризма, регулируют, прежде всего, деятельность туроператоров и турагентов, как основных участников, обладающих правом формировать, продвигать и реализовывать туристский продукт. Впервые законодательством предусматриваются требования к соответствию занимаемой должности - должностными лицами туроператора (руководителя туроператора, его заместителя, главного бухгалтера). К изменениям, внесенным в закон о туризме, также можно отнести нормы, регулирующие порядок представления электронных документов в единый федеральный реестр туроператоров, юридическим лицом, намеревающимся осуществлять туроператорскую деятельность [13, с. 140; 14, с. 42].

В 2018 г. основные изменения закона о туризме и в целом правового регулирования туристской индустрии, касались включения в состав участников правоотношений в сфере туризма и законодательного их закрепления - гостиниц и иных средств размещения, с указанием их правового статуса, в частности порядка классификации [3].

В 2019 г. изменения затронули организационную сторону, осуществления паломнической деятельности и паломнического туризма. В частности, если туристский маршрут предусматривает посещение туристом объектов показа, включая места религиозного почитания (паломничества), то обязанностью представителей туроператора является соблюдение порядка совершения богослужений, других религиозных обрядов и церемоний, контроль соблюдения туристами указанного порядка, а также требований к внешнему виду и поведению туристов и экскурсантов [4].

В 2021 г. в законодательство о туристской деятельности введены существенные дополнения. Так в состав участников туристских отношений вводится новый субъект - 
«субагент» - юридическое лицо или индивидуальный предприниматель, которым турагентом передано исполнение поручения туроператора на продвижение и реализацию туристского продукта и сведения, о которых внесены в единый федеральный реестр турагентов, субагентов. Так же определяется порядок ведения единого федерального реестра турагентов, субагентов [5]. Дополнительно приняты правовые нормы, конкретизирующие статус экскурсовода и инструктора-проводника они же устанавливают требования к аттестации указанных субъектов туристских отношений [6]. Важно учесть, что названные изменения вступают в силу соответственно с 1 января и 1 июля 2022 г. Логичным продолжением совершенствования правового регулирования туристской деятельности являлось-бы закрепление в законе о туризме положений, определяющих понятие экскурсии и экскурсионной услуги, например, экскурсионную услугу можно определить как «деятельность по организации экскурсии, предоставляемой в течение от одного (или более) астрономического часа в период времени до 24 часов вне места (или по месту) постоянного пребывания экскурсанта (или иного заказчика) с целью познания, организации культурного досуга, получения информации (культурного, исторического, религиозного и иного характера), расширения кругозора, а также организации общения и отдыха».

Помимо рассмотренных положений федеральных законов, к законодательным актам, отражающим изменения правового регулирования сферы туристской деятельности, можно отнести нормы, закрепляемые в подзаконных актах, например, постановлениях Правительства РФ от 11 августа 2020 г. № 1209 «Об утверждении Правил оказания экстренной помощи туристам и Правил финансирования расходов на оказание экстренной помощи туристам из резервного фонда объединения туроператоров в сфере выездного туризма» [7]; от 23 сентября 2020 г. № 1532 «Об утверждении Правил возмещения реального ущерба туристам и (или) иным заказчикам туристского продукта из денежных средств фонда персональной ответственности туроператора в сфере выездного туризма» [8]; от 30 июня 2021 г. № 1086 «О федеральном государственном контроле (надзоре) за деятельностью туроператоров и объединения туроператоров в сфере выездного туризма» [9]. Назначением данных документов, является закрепление правил, обеспечивающих права потребителей туристских услуг.

В заключении необходимо отметить, что в настоящее время в теории и практике развития правового регулирования деятельности в сфере туристской индустрии преобладают два направления:

В первом случае речь идет о принятии нормативно-правовых актов, устанавливающих и конкретизирующих правовой статус участников туристских и непосредственно связанных с ними общественных отношений, например включение в состав субъектов данных отношений - субагента, ранее в 2018 году в закон о туризме были внесены изменения, закрепляющие статус средств размещения, как одного из важнейших участников туристских отношений.

Во втором случае, можно говорить о нормах, устанавливающих правила соблюдения прав потребителей туристской услуги (туристов и экскурсантов) в части гарантирования финансовой составляющей туристской деятельности, например вопросы финансового обеспечения деятельности туроператоров и турагентов.

Все изменения и дополнения законодательных актов в сфере туристской деятельности, в конечном итоге направлены на обеспечение стабильности и гарантированности прав участников туристских отношений, а также на развитие данного вида экономической деятельности, способствующего как экономическому, так и политическому и культурному развитию российского государства.

$$
* * *
$$

1. «Об основах туристской деятельности в Российской Федерации» : федеральный закон от 24 ноября 1996 г. № 132-Ф3 // Собрание законодательства РФ. - 1996. - № 49. - Ст. 5491. 
2. «О внесении изменений в отдельные законодательные акты Российской Федерации в целях совершенствования законодательства, регулирующего туристскую деятельность» : федеральный закон от 02 марта 2016 г. № 49-Ф3 // Собрание законодательства РФ. - 2016. - № 10. - Ст. 1323.

3. «О внесении изменений в Федеральный закон «Об основах туристской деятельности в Российской Федерации» и Кодекс Российской Федерации об административных правонарушениях в целях совершенствования правового регулирования предоставления гостиничных услуг и классификации объектов туристской индустрии» : федеральный закон от 05 февраля 2018 г. № 16-Ф3 // Официальный интернетпортал правовой информации http://www.pravo.gov.ru, 05.02.2018.

4. «О внесении изменений в Федеральный закон «Об основах туристской деятельности в Российской Федерации» и Федеральный закон «О свободе совести и о религиозных объединениях» : федеральный закон от 03 июля 2019 г. № 170-Ф3 // Официальный интернет-портал правовой информации http://www.pravo.gov.ru, 03.07.2019.

5. «О внесении изменений в Федеральный закон «Об основах туристской деятельности в Российской Федерации» : федеральный закон от 24 марта 2021 г. № 48-Ф3 // Официальный интернет-портал правовой информации http://pravo.gov.ru, 24.03.2021.

6. «О внесении изменений в Федеральный закон «Об основах туристской деятельности в Российской Федерации» в части правового регулирования деятельности экскурсоводов (гидов), гидов-переводчиков и инструкторов-проводников» : федеральный закон от 20 апреля 2021 г. № 93-Ф3 // Официальный интернетпортал правовой информации http://pravo.gov.ru, 20.04.2021.

7. «Об утверждении Правил оказания экстренной помощи туристам и Правил финансирования расходов на оказание экстренной помощи туристам из резервного фонда объединения туроператоров в сфере выездного туризма» : постановление Правительства РФ от 11 августа 2020 г. № 1209 // Официальный интернет-портал правовой информации http://www.pravo.gov.ru, 13.08.2020.

8. «Об утверждении Правил возмещения реального ущерба туристам и (или) иным заказчикам туристского продукта из денежных средств фонда персональной ответственности туроператора в сфере выездного туризма» : постановление Правительства РФ от 23 сентября 2020 г. № 1532 // Официальный интернет-портал правовой информации http://www.pravo.gov.ru, 29.09.2020.

9. «О федеральном государственном контроле (надзоре) за деятельностью туроператоров и объединения туроператоров в сфере выездного туризма» : постановление Правительства РФ от 30 июня 2021 г. № 1086 // Официальный интернет-портал правовой информации http://pravo.gov.ru, 02.07.2021.

10. Конт-Спонвиль А. Философский словарь / Пер. с фр. Е.В. Головиной. - М.: Этерна, 2012. - 752 с.

11. Лебедев С.А. Философия науки: краткая энциклопедия (основные направления, концепции, категории). Научное издание / С.А. Лебедев. - М.: Академический Проект, 2008. - 692 с.

12. Отческий И.Е. Защита прав потребителей в обязательствах по возмездному оказанию туристских услуг: монография / И.Е. Отческий - М.: Юстицинформ, 2017. - 264 с.

13. Удалов Д.Э. законодательные новеллы государственного регулирования туристской деятельности // Индустрия туризма: возможности, приоритеты, проблемы и перспективы. 2016. Т. 9. № 2. С. 139-145.

14. Удалов Д.Э. К 20-летию закона о туризме (перспективы правового регулирования туристских отношений) // Научный вестник МГИИТ. 2016. № 6 (44). С. 38-49.

15. Удалов Д.Э. Источники правового регулирования туристской деятельности // Туризм: право и экономика. 2018. № 4. С. 7-12.

16. Юридическая техника. В 2 т. Том 1: учебник для вузов / под ред. В.М. Баранова. - М.: Издательство Юрайт, 2016. -251 с.

17. Юридический энциклопедический словарь / под ред. А.В. Малько. - 2-е изд. - Москва: Проспект, 2017. $1136 \mathrm{c}$.

\section{Фесюн М.В., Редников Д.В. \\ Понятие, сущность прокурорского надзора и полномочия прокуратуры Российской Федерации}

Башкирский государственный университет

(Россия, Уфа)

doi: $10.18411 /$ trnio-11-2021-268

\section{Аннотация}

Органы прокуратуры занимают особое место в структуре российского государства. Они имеют функциональное отношение к ветвям власти, установленным Конституцией России. Не обращаясь полностью ни к одному из них, прокурорский надзор позволяет сбалансировать их и обеспечить оптимальное функционирование. При рассмотрении сущности вышеуказанного вида деятельности следует отметить многообразие его 